\title{
BEGINNINGS AND DEVELOPMENT OF RUGBY IN SPAIN
}

\author{
Carlos Castellar ${ }^{1}$ and Francisco Pradas ${ }^{1}$ \\ ${ }^{1}$ University of Zaragoza, Faculty of Human Sciences and Education, Spain
}

UDK 793/799:796.333(460)

\section{SUMMARY}

The annals of rugby in Spain dates from the early years of the 20th century. In its early stages, the influence of countries such as England (due to its industries and commerce) or France (due to its geographical proximity) was very significant. The period of dictatorship (1940-1975) did not aid in developing this sport in Spain, though. Since democracy, rugby has consolidated its progression both in the masculine category and mainly in the feminine. The Spanish female rugby team is recognized as one of the best international teams. In this sense, the number of federative licenses has doubled in the last 20 years, going from 14,000 to more than 33,000 in 2018. In addition, adapted rugby has joined in this trend with the creation of a national wheelchair rugby team and federated competitions.

Keywords: history, rugby, review, Spain

Corresponding author

Carlos Castellar

castella@unizar.es

\section{INTRODUCTION}

The purpose of this study was to find and make all the information and data available to those who are interested in the origins of rugby in Spain. Existing information is scattered geographically and fragmented as shown in the analyzed databases, in the absence of rigorous research. For this reason, the information consulted has been collected and compiled in four sections as follows: federative development, development of rugby, most outstanding players, clubs and national team, female rugby in Spain and adapted rugby. Our interest is to provide young 
researchers with a starting point to produce a monograph that includes detailed data about rugby in Spain.

\section{MATERIALS AND METHODS}

The study was carried out from December 2019 to April 2020. It consisted in the analysis of reference materials from libraries, universities and information centers such as the Spanish rugby federation. Likewise, databases, published interviews, press releases, records and biographies have been consulted. The information has been processed, classified and structured presenting it chronologically.

Bibliographical references used in the review included studies carried out to March 2020. The applied search strategy included the following terms: "rugby" and "rugby history Spain".

\section{FEDERATIVE DEVELOPMENT}

The Spanish Rugby Federation (figure 1) was created in 1923. The first official club competition in Spain was held during the 1925-26 seasons called Spanish Rugby Championship. Later in 1934 Catalonia became part of the founding countries of the International Amateur Rugby Federation (FIRA), thanks to the rights granted by its 1932 Statute of Autonomy. It was recognized as a full member of the FIRA along with the state federations of France, Italy, and Germany, Czechoslovakia and Romania. At first this fact caused political and sports difficulties amongst the Catalan Federation and the Spanish Federation, since the latter also wanted to join the FIRA. Finally, the Spanish Federation was accepted as a member of the FIRA under the same conditions.

\section{FERugby}

Figure 1. Spanish rugby federation logo

Around this time, the Catalan Federation organized its own competition in parallel, playing different official international matches against teams such as France or Italy. This National Federations duplicity continued until 1940, from 
this point in time the activities of the Catalan Federation were prohibited, and throughout the period of the dictatorship (1940-1975). The Spanish Rugby Federation has been a member of the International Rugby Board (IRB) since 1988, better known since its Foundation in 1886 as the International Rugby Football Board.

Rugby leagues, coordinated by the Spanish Federation, have three different categories or levels. The Honorary Division lies on the first level with 12 teams currently. The Honorary Division B formed in the 2019-20 season by 36 teams is divided into three groups. Finally, the Regional Leagues are at the third level. Furthermore, there are two existing levels in the female category. The Honorary Division formed by 8 teams is at Level 1 whereas the Regional Leagues are at level 2. The latest are organized by the Territorial Federations for both the male and the female categories. Moreover, the Spanish Federation coordinates the championship starting and ending dates in order to establish the Play-Off dates for de Honorary Division promotion. In addition to the aforementioned leagues, the Spanish Super Cup and King's Cup are federal competitions included.

The federative work for the young player categories is divided into two programs: the lower categories and the base rugby. The lower categories are the players sub20 (U20), sub18 (U18) and sub16 (U16). Base rugby consists of sub14 (U14), sub12 (U12), sub10 (U10), sub8 (U8) and sub6 (U6).

Lastly, the number of federative licenses has increased significantly over the 21st century, going from 14,807 licenses in 2000 to more than 33,000 in the 201617 season (figure 2).

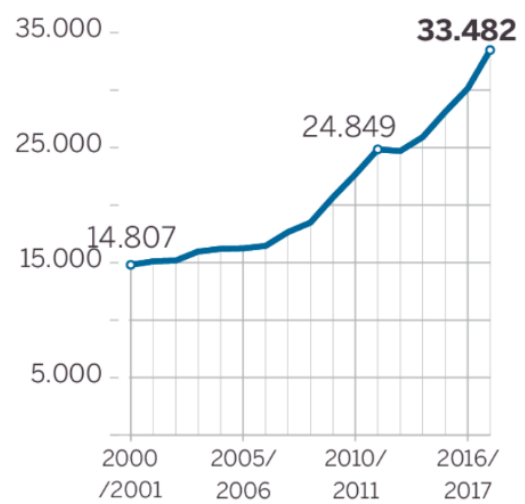

Figure 2. Evolution of federative licenses between the years 2000-2017 (Source: Spanish Rugby Federation cited by El País newspaper) 


\section{SPORT DEVELOPMENT}

Rugby took its first steps in Spain similarly to other sporting disciplines from France or the United Kingdom. In the early twentieth century rugby matches were played mostly in the mining areas of Andalusia, in southern Spain, since these zones were exploited by the British. Huelva, one of these cities published in its local press the first written reference of these sporting events which dates from 1906. Similar events took place at that time in the border areas with France (Basque Country and Catalonia) as there is evidence of the rugby practice in those areas.

The first known report about rugby played in Spain took place between English sailors from two ships anchored in the port of La Coruña in the northwest of the country. There were two teams: Gloucester and Liverpool and the match happened on March 2nd, 1911 (the victory was for the Gloucester crew by five to one). In May, that same year, an exhibition match took place between the Club Deportivo Español and the Patrie (a team of French men living in Barcelona) as documented. The French won 7-0.

Ten years later, in 1921, a Spanish veterinary student in France took the initiative of making known rugby in Spain through Catalonia. Baldiri Aleu Torres named the club the Unió Esportiva Santboiana based in San Baudilio de Llobregat, a city nearby Barcelona. The Horse Racing Society Cup was created in 1922, it was the first official Rugby competition ascertained in Spain. The final was disputed by the EU Santboiana and the Barcelona Swimming Club, with a victory of the former by 3 to 0 . Since the creation of the Spanish Rugby Federation in 1923, the rules and structures for a homogeneous rugby practice were established throughout the territory.

\section{PROMINENT PLAYERS, CLUBS AND NATIONAL SELECTION}

The first competition between clubs in Spain was organized after the creation of the Spanish Federation in 1923, it was known as the Spanish Rugby Championship (currently called the Copa del Rey). The main Spanish clubs were founded during the 1920-1940 period. As previously mentioned, the UE Santboiana was the dean club and seven times winner of the Honorary Division. Besides, the Architecture club was the second outstanding club to be founded. The club only participated in university competitions at its inception, but since 1964, after joined the federated competition, it has ceaselessly achieved titles, and it has became the most successful club in Spain nowadays.

One of the most noteworthy clubs was Cisneros founded in 1943. It takes part in the Division of Honor club currently, having several league trophies on his record. Other clubs, which are the sport elite in Spain nowadays, were appeared 
successively: Canoe (Madrid), Getxo (Basque Country), La Vila (Alicante), El Salvador (Valladolid), VRAC (Valladolid), the CAU (Valencia) or the Hernani (Basque Country). Official competitions in Spain were consolidated during the last third of the XX century, contributing to the expansion of rugby.

Regarding the most outstanding Spanish players in the recent history of Spanish rugby, it must be highlighted Manuel Moriche, player of the Arquitectura club from the '70s to the '80s. In words of Ray Williams, legendary Welsh rugby manager, as an example of this player quality: "Moriche could have played without problem in the starting position of any team in the Five Nations Tournament." He was 59 caps for Spain taking part of the selection. However, a different player, Francisco Puertas (left wing) outnumbers this number with 93 presences as international for Spain. They are followed by Jaime Nava (flanker) and Jon Azkargorta (full back) with 79 and 76 participations in the national team. Above this threshold (70 matches) José Julio Alvarez (prop), Alberto Malo (flanker) and Alvar Enciso (inside center) appear with 75, 74 and 70 participations, respectively.

The national team of Spain is known, in reference to the logo of the federation, as the XV of the Lion. Their first sport meeting was played four years after the creation of the Spanish federation against France in 1927 (the outcome was 6-66 defeat). On May 20, 1929, the first official match against the Italian team was held, with a favorable result of 9-0. During the period from 1930 to 1940, many matches were played against other European national teams with mostly positive results. In the decade from 1940 to 1950 Spain was in the throes of a serious postwar period, stopping playing any game until 1951. This situation caused a loss of its competitive capacity, therefore being unable to overcome rivals such as Italy or Germany. It was not until the 60s and 70s that Spain recovered its previous international level. In 1980 and 1982 the team had the opportunity to face toplevel teams, such as Argentina or New Zealand. In 1988 they repeated a game against New Zealand, making one of the most complete events reminded in the history of the XV of the Lion, despite the12-21 loss.

The only participation of the national team rugby in the World Cup was in the 1999 edition. Although, there were obvious differences between a professional team such as Australia and a second row one such as the Spanish team, as it could be shown in its 2001 tour around Spain.

In this sense, the national team has progressed in its game until reaching the so-called VI Nations "B" in Europe, along with teams such as Belgium, Russia, Georgia and Romania. One of the reasons for this progression is due to the incorporation of foreign players in the league. They are athletes who have previously played in leagues such as the French and provide a technical and tactical experience enhancing expertise towards the high level needed. Nowadays, 
the Spanish team matches are played on the Central Field of the University City of Madrid, with a capacity for 16,000 spectators.

The federation has also opted for the rugby-7 team achieving a commendable classification for the Rio de Janeiro Olympic Games in 2016. Furthermore, the team has three participations in the World Cup, obtaining a tenth place in the 1993 edition.

The track record of the national team throughout its history is the following:

FIRA Nations Cup Championship (division 2): 1971-1972, 1979-1980, 1985 1987 and 1989-1990.

- $\quad$ European Nations Cup Championship (division 2): 2004-06.

- European Nations Cup runner-up (division 1): 2012.

- Rugby Europe International Championship runner-up (division 1): 2019.

\section{WOMEN'S RUGY IN SPAIN}

Women's rugby started like other sports disciplines in Spain, almost parallel to the history of men's rugby but doing it in a hidden form. The society of the early twentieth century disagreed with the practice of these sport disciplines by women. Thus, Spanish history between the 1940s and 1970s did not contribute to the development of women's sport in general, rugby in particular, being coterminous with General Franco's dictatorship.

Given this context, it was not until the 70s of the last century that a group of student girls from the Higher School of Architecture of Madrid began training twice a week. Gradually but constantly, other women were incorporated until they reached a score. They used to play matches spontaneously due to the lack of female teams in the rest of Spain. A few years later, at the end of the 1970s, José Antonio Sancha (rugby professor at the National Institute of Physical Education of Barcelona, INEFC) began to train a group of female players regularly together with the university masculine team. However, the Catalan Rugby Federation did not recognize them as a team until 1983. As a matter of fact, the first women's rugby match in Spain opposed two teams from Barcelona (INEFC and BUC). At that time there were only women's clubs in Barcelona and Madrid.

Over the next few years, women's rugby in Spain expanded the amount of practitioners, clubs and places where it was played. Clubs were created in Valencia, Andalusia, Basque Country, etc. In 1991 there were 27 women's rugby teams which competed recognized by the Federation of rugby. There are currently more than 200 clubs and its expansion has been very important, not only quantitatively but qualitatively. 
The women's national rugby team, known as "the Lionesses", had its international premiere in 1991 on the Rugby World Cup held in Wales. They finished in fifth position behind the United States, England, France and New Zealand. Despite not being able to attend the World Cup held in Scotland in 1994 due to financial problems in the Federation, the Spanish women's team is still one of the greatest at the international level. This is also well illustrated by the European Championship achieved in Italy, defeating the French team in the final game by 21 to 6 . The following year, in 1997, they reached the runner-up position in the same tournament.

Later, in the 1997 European Championship, the first European Tournament where all the English teams participated, they obtained a creditable third place, behind the two finalist teams: Scotland and England. Since the beginning of the 21st century, the national team has continued reaping international successes. The team has proven a remarkable progression and potential to perform at the higher level in spite of the lack of tradition in rugby in Spain as well as the lack of economic support and support in the media as compared to other teams on the international stage. The following list summarizes its main honors from the year 2000:

- Rugby World Cup: Spain 2002 (8th place), Canada 2006 (9th place), France 2014 (9th place) and Ireland 2017 (10th place).

- Six Nations: year 2000 (3rd place), year 2001 (2nd place), year 2002 (3rd place), and year 2004 (3rd place).

- European Rugby Championship: Spain 2000 (2nd place), France 2001 (2nd place), Sweden 2003 (Champions), Spain 2007 (3rd place), France 2010 (Champions), Spain 2011 (2nd place), Spain 2013 (Champions), Spain 2016 (Champions), Belgium 2018 (Champions), Spain 2019 (Champions).

The players with the highest number of participations in the women's national team are Inés Etxegibel (fly half) and Aroa González (hooker) with 64 participations each. Rocío García (prop), Isabel Rodríguez (scrum half) and Pilar López (second row) also have 58, 56 and 49 participations, respectively.

\section{RUGBY AND ADAPTED SPORT}

The Spanish Sports Federation of handicapped athletes (figure 3) has recently created official wheelchair rugby competitions. In this sense, the Catalan city of Cervera organized the first Spanish Championship for the CCAA. Due to this event, the Federation decided to include in its regulations the specialty of rugby adapted 
for people with physical disabilities, being the basis for the creation of the national team.

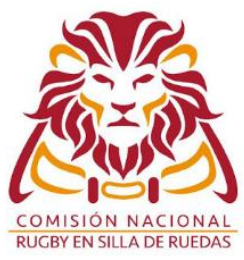

Figure 3. Spanish adapted rugby federation logo

This sports project is called "Lions on wheels" and intends to develop wheelchair rugby throughout the Spanish territory. At the moment, Spanish rugby is within the European $\mathrm{C}$ level after recently joined the international context. In order to be promoted to level B, it should achieve a first or second place in the Play-Off for promotion. Level A is still a long way off for such a young project whereas other countries have more than twenty years of experience in developing adapted rugby.

\section{REFERENCES}

1. Escario, J. Breve historia del Rugby Español. Accessed April 14, 2020, https://academiaplay.es/breve-historia-rugby-espanol/.

2. Federación Española de Deportes con de personas con discapacidad física. Accessed April 4, 2020, http://www.feddf.es/seccion-deporte/487/rugby/asi-esel-rugby.html.

3. Federación Española de Rugby. Accessed March 29, 2020, http://ferugby.es/bienvenida.

4. Gounot, A., \& Laorden, M. T. "El rugby español de ayer y de hoy". Apropos [Perspektiven auf die Romania] (2), (2019): 133-142, doi:10.15460/apropos.0.1403.

5. Javier, L. "El rugby en España, un deporte en crecimiento". El País (March 19, 2018). https://elpais.com/deportes/2018/03/18/actualidad/1521378320_144485.html

6. Martínez, J. C., Martínez, A. C., \& Fernández, A. C. Patrimonio histórico español del juego y del deporte, 2012, Federación Española de Rugby.

7. Rugby femenino. Accessed February 23, 2020, https://rugbyfemenino.com.es/leonas/.

8. Usero, R. \& Rubia, A., Rugby Madrid, España: Ministerio de Educación y Ciencia, 1996), 15-18. 


\begin{abstract}
АННОТАЦИЯ
Зарождение регби в Испании датируется первой половиной 20-го века. На ранних этапах развития регби испытывает значительное влияние таких стран, как Англия (благодаря промышленности и торговле) или Франция (благодаря географической близости). Однако период диктатуры (1940-1975) не способствовал развитию этого вида спорта в Испании. С установлением демократии регби укрепилось и в мужской категории, и преимущественно в женской. Испанская женская сборная по регби признана одной из лучших международных команд. В этом смысле количество федеративных лицензий за последние 20 лет удвоилось - от 14000 до более чем 33000 в 2018 году. Кроме того, регби, приспособленное для людей с ограниченной подвижностью, присоединилось к этой тенденции с создания национальной команды по регби на колясках и организации федеративных соревнований.
\end{abstract}

Ключевые слова: история, регби, обзор, Испания

Reccived on 18.04.2020.

Accepted on 19.05.2020. 